\title{
Evaluation of Anti-inflammatory Activity of Crinum scillifolium Extracts in Wistar Rats
}

\author{
Koua Kadio Brou Donald ${ }^{1, *}$, Irié-N'guessan Amenan Geneviève ${ }^{2}$, Effo Kouakou Etienne ${ }^{2}$, \\ Kouakou Sylvain Landry², Ayoman Thierry Lenoir djadji², Tetchi Achille Fabrice ${ }^{3}$, \\ Yapi Houphouët Felix ${ }^{1}$

\footnotetext{
${ }^{1}$ Laboratory of Biochemical Pharmacodynamics, UFR Biosciences, Felix Houphouët-Boigny University, Côte d'Ivoire

${ }^{2}$ Department of Pharmacology, Clinical and Therapeutical Pharmacy UFR Pharmaceutical and Biologic Sciences, Felix Houphouët-Boigny University, Côte d'Ivoire

${ }^{3}$ Laboratory of Food Biochemistry and Tropical Products Technology, University of Nangui Abrogoua, Côte d'Ivoire
}

Copyright $\bigcirc 2018$ by authors, all rights reserved. Authors agree that this article remains permanently open access under the terms of the Creative Commons Attribution License 4.0 International License

\begin{abstract}
Aim of study: Inflammation was associated with many diseases in humans. Crinum species have a considerable medicinal reputation as potent folkloric remedies. The main objective of the study was to evaluate the anti-inflammatory activity of aqueous and hydroethanolic extracts of Crinum scillifolium bulbs in in vivo models. Materials and methods: The anti-inflammatory effect of Crinum scillifolium extracts was also evaluated in carrageenan-induced paw edema models and C-reactive protein (CRP) levels was measured. Two doses 100 and $200 \mathrm{mg} / \mathrm{kg}$ body weight for each extract, were tested. The results obtained were compared with those of the standard drug (Diclofenac at $25 \mathrm{mg} / \mathrm{kg}$ body weight) and those of the control (normal saline). Results: The results showed a highly significant decrease in the edema size $(p<0.01)$ and significant decrease in CRP values $(\mathrm{p}<0.01)$ compared to control group when the animals were treated with diclofenac at $25 \mathrm{mg} / \mathrm{kg}$, and 200 $\mathrm{mg} / \mathrm{kg}$ of aqueous and hydroethanolic extracts. Conclusion: The study suggests that the extracts possess enough potential to reduce inflammation on rat model and directs the importance of further research and development of novel anti-inflammatory agents.
\end{abstract}

Keywords Crinum scillifolium, Inflammation, CRP, Carrageenan

\section{Introduction}

Inflammation is a transitory nonspecific biological response of the microcirculation to tissue damage or pathogen infection. This process occurs as a defensive mechanism, which induces profound physiological adaptations in an attempt to limit tissue damage and remove the pathogenic insult [1]. Usually, during acute inflammatory responses, cellular and molecular events and interactions efficiently minimize impending injury or infection. This mitigation process contributes to restoration of tissue homeostasis and resolution of the acute inflammation. However, uncontrolled acute inflammation may become chronic, contributing to a variety of chronic inflammatory diseases such as neurodegenerative and cardiovascular diseases $[2, \mathbf{3}]$.

The only available medicine in modern practice are cyclooxygenase (COX) inhibitors i.e. NSAIDs. The use of these classical medicine for long term treatment, produces severe adverse effects such as renal damage, gastrointestinal disturbances, respiratory depression, and possible dependence [4]. Therefore, new anti-inflammatory drugs lacking those effects are being searched all over the world as alternatives. Medicinal plant have great value so that, the study of plants that have been traditionally used as anti-inflammatory killers should still be seen as a fruitful and logical research strategy in the search for new anti-inflammatory [5].

Crinum species have a considerable medicinal reputation as potent folkloric remedies. Their use extended from the ancient times to nowadays especially in Africa, tropical Asia and South America [6, 7]. Several Crinums are commonly used in treatment of various painful and inflammatory disorders such as rheumatism, earache, lumbago, edema, headache, swelling, backache, wounds and haemorrhoids $[7,8,9,10]$, and pharmacological investigation of the effects of total extracts obtained from different parts of Crinums using many algesiometric and inflammatory models showed their potential for treatment of various pains and inflammatory processes [11]. From the above context, the study was designed to evaluate the anti-inflammatory effect of Crinum scillifolium in rat model. 


\section{Materials and Methods}

\subsection{Extracts Preparation}

\subsubsection{Aqueous Extract}

Fifty gram $(50 \mathrm{~g})$ of the bulbs powder was macerated in $500 \mathrm{ml}$ of distilled water for 48 hours with stirring at $25^{\circ} \mathrm{C}$. The liquid extract obtained after filtration through hydrophilic cotton followed by Whatman filter paper was evaporated to dryness in an oven at a temperature of $40^{\circ} \mathrm{C}$. The extract was stored in refrigerator $\left(4^{\circ} \mathrm{C}\right)$ until ready use. Various concentration were reconstituted in distilled water for biological tests.

\subsubsection{Hydroethanolic Extract}

Guédé-Guina (1990) method was used with slight modification: fifty gram $(50 \mathrm{~g})$ of bulbs powder was macerated in $500 \mathrm{ml}$ of hydroethanolic solution $90 \%$ (ethanol/water 90:10) for 48 hours with stirring at $25^{\circ} \mathrm{C}$ [12]. The liquid extract obtained after filtration through Whatman filter paper was evaporated to dryness in an oven at a temperature of $40^{\circ} \mathrm{C}$. The extract was stored in refrigerator $\left(4^{\circ} \mathrm{C}\right)$ until ready use. Various concentration were reconstituted in distilled water for biological tests.

\subsection{Animals}

Wistar albinos rats $(150-180 \mathrm{~g})$ of either sex were used in this study. The animals were housed in appropriate cages at $24^{\circ} \mathrm{C}$ on a $12 \mathrm{~h}$ light/dark cycle with free access to food and water in the Laboratory Animal (UFR Pharmaceutical and Biological Sciences; University Félix Houphouët-Boigny). In all the experimental studies, each group consisted of six animals. Each animal was used only once. The investigation conforms to the recommendation of the Organization for Economic Co-operation and Development (OECD) in 2008 [13]. Before the experiment, the mice were divided into homogeneous lots by weight.

\subsection{Test for Anti-inflammatory Activity}

\subsubsection{Carrageenan Induced Paw Edema in the Rat}

Adult male and female Wistar rats were used for the study. An edema was induced on rat's right hind paw by subplantar injection of $0.2 \mathrm{ml}$ of $1 \%$ carrageenan in $0.9 \%$ saline. The experimental groups consisted of 36 rats divided into six groups

$>$ Group 1 served as the negative control and $10 \mathrm{ml} / \mathrm{kg}$ bw Nacl $0.9 \%$ was orally administered;

$>$ Groups 2 and 3 were administered the aqueous extract respectively at the dose of 100 and $200 \mathrm{mg} / \mathrm{kg}$ bw was orally administered;

$>$ Groups 4 and 5 were administered the hydroethanolic extract respectively at the dose of 100 and $200 \mathrm{mg} / \mathrm{kg}$ bw was orally administered;
Group 6 served as the positive control and Diclofenac at a dose of $25 \mathrm{mg} / \mathrm{kg}$ bw was intraperitoneally administered;

One hour after the pretreatment, $0.2 \mathrm{~mL}$ of Carrageenan (1\%) was injected into the subplantar tissue of the right hind-paw of each rat. The diameter of each paw was measured using digital paw edema meter. The measures were carried out at $0 \mathrm{~h}\left(\mathrm{D}_{0}\right.$ : before carrageenan injection) and 1, 2, 3, 4, 5, 6 and $24 \mathrm{~h}$ after induction of inflammation $\left(\mathrm{D}_{\mathrm{T}}\right)$. The difference between $\mathrm{D}_{\mathrm{T}}(1,2,3,4,5,6$ and $24 \mathrm{~h})$ and $\mathrm{D}_{0}$ was taken as the edema diameter value. The percentages of inhibition were calculated according to the following formula $[14,15]$ :

$\%$ Inhibition $=\frac{\left.\left[\left(D_{T}-D_{0}\right) \text { control }-\left(D_{T}-D_{0}\right) \text { treated group }\right)\right]}{\left(D_{T}-D_{0}\right) \text { control }} * 100$

\subsubsection{Quantitative Measurement of Rat C Reactive-Protein} (CRP) in Serum

Thirty six new rats either sex were divided into six groups $(\mathrm{n}=6)$

$>$ Group 1 served as the negative control and $10 \mathrm{ml} / \mathrm{kg}$ bw Nacl $0.9 \%$ was orally administered;

$>$ Group 2 served as the normal control and $10 \mathrm{ml} / \mathrm{kg}$ bw Nacl $0.9 \%$ was orally administered;

$>$ Groups 3 was administered the aqueous extract at $100 \mathrm{mg} / \mathrm{kg}$ bw was orally administered;

$>$ Groups 4 was administered the hydroethanolic extract at $100 \mathrm{mg} / \mathrm{kg}$ bw was orally administered;

$>$ Group 6 served as the positive control and Diclofenac at a dose of $25 \mathrm{mg} / \mathrm{kg}$ bw was intraperitoneally administered;

One hour after the pretreatment, $0.2 \mathrm{~mL}$ of Carrageenan (1\%) was injected into the subplantar tissue of the right hind-paw of each rat without group 2. After $5 \mathrm{~h}$ carrageenan administration, all the animals were sacrified and blood were collected and serum was separated. The dosage of the CRP was performed according to the method of Immunoturbidimetry improved particles in the Erba XL 180 (Mannheim) [16]. It is based on the principle of agglutination of latex particles coated with specific antibodies.

\section{Results}

\subsection{Carrageenan-induced Paw Edema}

The results obtained show that all rat injected with carrageenan developed a paw edema. The volume of paw edema varies with time. After one hour of carrageenan injection, the statistical study showed no significant difference between the control group paw diameter and those of the groups treated with aqueous and hydroethanolic extract of Crinum scillifolium (100 and 200 $\mathrm{mg} / \mathrm{kg}$ body weight) and Diclofenac $(25 \mathrm{mg} / \mathrm{kg}$ body 
weight). For animal received saline solution, the edema increased to reach a peak characteristic of an inflammatory reaction at the 4rd and 5rd hour and then decreased at the 6th hour, without reaching the initial volume (normal state) The anti-inflammatory activity data indicated that all the test concentrations $(100$ and $200 \mathrm{mg} / \mathrm{kg}$ ) were able to significantly reduce the carrageenan-induced edema at different time after the injection of the phlogistic agent, in comparison to control $(\mathrm{p}<0.001)$ in a dose-dependent manner with increased activity after 2 hours. Hydroethanolic extract at $200 \mathrm{mg} / \mathrm{kg}$ reduced edema significantly $(\mathrm{p}<0.01)$ compared with the edema of the control group at 2, 3, 4, 5, 6 and 24 hour (Table I). The hydroethanolic extract at $100 \mathrm{mg} / \mathrm{kg}$ showed significant inhibition of carrageenan-induced rat paw edema from 4 hours following inflammation induction, compared to the control group. Oral administration of aqueous extract at 100 and $200 \mathrm{mg} / \mathrm{kg}$ reduced edema significantly $(\mathrm{p}<0.01)$ compared with the edema of the control group at 4, 5, 6 and 24 hour. Interestingly, the reduction of the edema by aqueous extract of Crinum scillifolium at the dose of 200 $\mathrm{mg} / \mathrm{kg}$ was similar to the standard used (diclofenac) throughout the entire period of observation (Table I). Anti-inflammatory activity of crinum scillifolium extracts was expressed as a percentage of inhibition of inflammatory edema (Table II). During the first six hours of the experiment, the results showed that the Diclofenac at
$25 \mathrm{mg} / \mathrm{kg}$ exhibited the highest anti-inflammatory activity, with percentage of inhibition ranging between 46.49 and $71.62 \%$ followed by aqueous and hydroethanolic extracts at $200 \mathrm{mg} / \mathrm{kg}$, with percentage inhibition ranging from 37.7 to $60.13 \%$ and from 46.46 to $55.31 \%$ respectively. While the aqueous and hydroethanolic extracts at $100 \mathrm{mg} / \mathrm{kg}$ allowed the lowest inhibitory power with percentages of inhibition ranging between 21 to $46 . \%$ and 11.11 to $32.18 \%$ respectively. However, after 24 hours of the experimentation, aqueous extract at $200 \mathrm{mg} / \mathrm{kg}$ exhibited the highest anti-inflammatory activity than Diclofenac, with percentage of inhibition to $82.22 \%$ and $73.33 \%$ respectively

\subsection{Effect of Crinum scillifolium Extract on Serum Levels CRP at 5th Hour during Carrageenan induced Paw Edema in Rats}

By results of biochemical researches it is established that the increase of the $\mathrm{C}$ reactive protein level is noted which is more expressed in control group (Nacl + carrageenan). Oral administration the plant extracts decreased a significant $(\mathrm{P}<0.001)$ the concentration of $\mathrm{CRP}$ induced by the injection of carrageenan compared to the control. Intensity of this effect was comparable to that Diclofenac at $25 \mathrm{mg} / \mathrm{kg}$ bw (Figure 1)

Table I. Effect of Aqueous and hydroethanolic extracts of Crinum scillifolium bulbs and diclofenac on carrageenan rat paw edema.

\begin{tabular}{|c|c|c|c|c|c|c|c|}
\hline \multirow{2}{*}{$\begin{array}{c}\text { Traitements } \\
(\mathrm{mg} / \mathrm{kg})\end{array}$} & \multicolumn{7}{|c|}{ Variations of paw edema (mm) } \\
\cline { 2 - 8 } & T 1h & T 2h & T 3h & T 4h & T5h & T 6h & T 24h \\
\hline Nacl 10 ml/kg & $0.99 \pm 0.26$ & $1.07 \pm 0.17$ & $1.41 \pm 0.27$ & $1.765 \pm 0.56$ & $1.56 \pm 0.28$ & $1.48 \pm 0.43$ & $1.35 \pm 0.45$ \\
\hline EA 100 & $0.78 \pm 0.50$ & $0.78 \pm 0.35$ & $0.92 \pm 0.41$ & $0.95 \pm 0.41^{* *}$ & $1.08 \pm 0.42^{*}$ & $0.84 \pm 0.31^{* *}$ & $0.75 \pm 0.33^{*}$ \\
\hline EA 200 & $0.62 \pm 0.4$ & $0.79 \pm 0.48$ & $0.9 \pm 0.46$ & $0.75 \pm 0.25^{* * *}$ & $0.67 \pm 0.22^{* * *}$ & $0.59 \pm 0.16^{* * *}$ & $0.24 \pm 0.09 * * *$ \\
\hline EHE 100 & $0.88 \pm 0.4$ & $1.18 \pm 0.2$ & $1.16 \pm 0.22$ & $1.197 \pm 0.19^{*}$ & $1.26 \pm 0.20$ & $1.10 \pm 0.17$ & $0.87 \pm 0.18$ \\
\hline EHE 200 & $0.53 \pm 0.4$ & $0.54 \pm 0.36^{*}$ & $0.63 \pm 0.45^{* *}$ & $0.80 \pm 0.41^{* * *}$ & $0.80 \pm 0.41^{* * *}$ & $0.90 \pm 0.36^{*}$ & $0.55 \pm 0.35^{* * *}$ \\
\hline Diclo 25 & $0.5 \pm 0.17$ & $0.62 \pm 0.15$ & $0.6 \pm 0.19^{* *}$ & $0.7 \pm 0.20^{* * *}$ & $0.68 \pm 0.09^{* * *}$ & $0.42 \pm 0.06^{* * *}$ & $0.36 \pm 0.08^{* * *}$ \\
\hline
\end{tabular}

The results are expressed as means \pm standard deviation at risk $\alpha=5 \%$; ${ }^{*}<0.05, * * p<0.01,{ }^{* * *} \mathrm{p}<0.001$ compared to control (Nacl) (ANOVA test followed by Dunnett test)

Table II. Inhibition (\%) of inflammatory paw edema by Crinum scillifolium extracts and Diclofenac.

\begin{tabular}{|c|c|c|c|c|c|c|c|}
\hline \multirow{2}{*}{ Traitements } & \multicolumn{9}{|c|}{ \% Inhibition of paw edema } \\
\cline { 2 - 9 } & T $1 \mathrm{~h}$ & T 2h & T 3h & T 4h & T5h & T 6h & T 24h \\
\hline EA $100 \mathrm{mg} / \mathrm{kg}$ & 21 & 22.42 & 34.75 & 46.17 & 30.76 & 43.24 & 44.44 \\
\hline EA $200 \mathrm{mg} / \mathrm{kg}$ & 37.37 & 26.16 & 36.17 & 57.50 & 57.05 & 60.13 & 82.22 \\
\hline EHE $100 \mathrm{mg} / \mathrm{kg}$ & 11.11 & 11.11 & 17.73 & 32.18 & 19.23 & 25.67 & 35.55 \\
\hline EHE $200 \mathrm{mg} / \mathrm{kg}$ & 46.46 & 49.53 & 55.31 & 54.67 & 48.71 & 39.18 & 59.25 \\
\hline Diclo $25 \mathrm{mg} / \mathrm{kg}$ & 49.49 & 42.05 & 57.44 & 60.33 & 82.22 & 71.62 & 73.33 \\
\hline
\end{tabular}




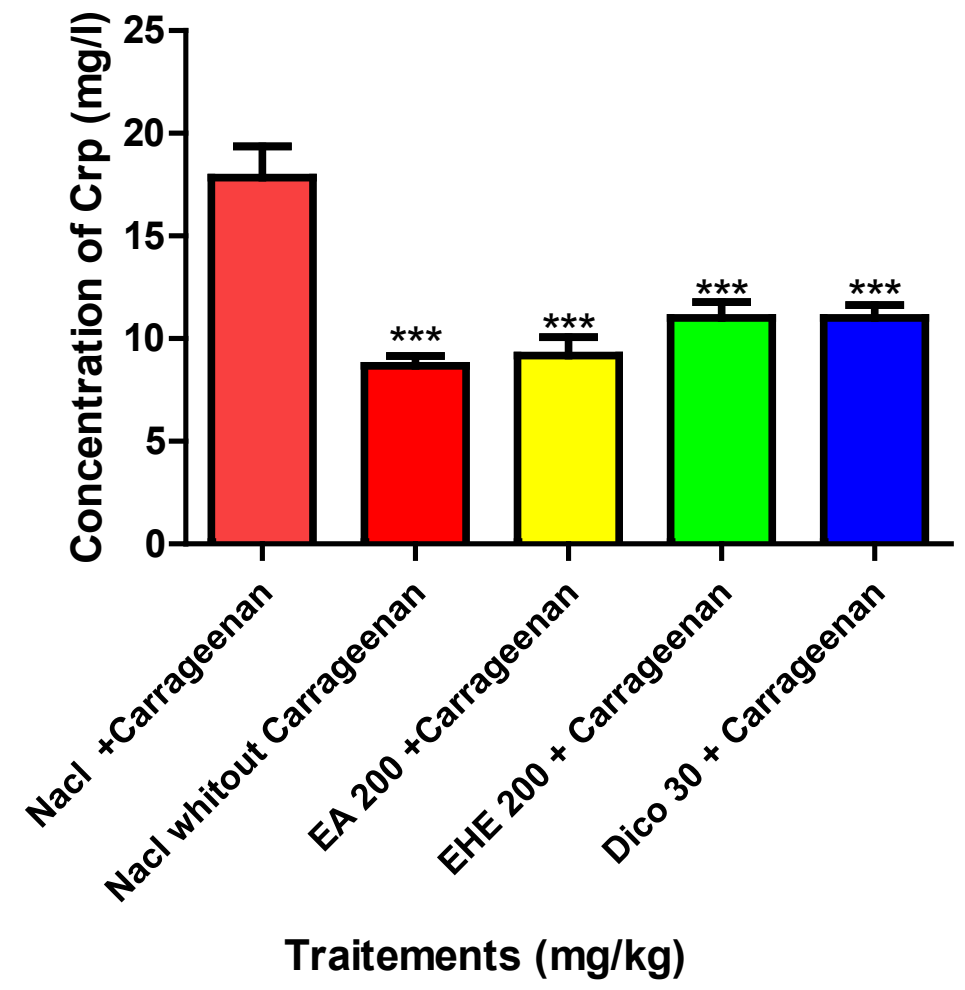

Figure 1. Effect of Crinum scillifolium extracts on serum CRP concentration 5 hours after injection of the carrageenan. The results are expressed as means \pm standard deviation at risk $\alpha=5 \% ;{ }^{*} \mathrm{p}<0.05,{ }^{* *} \mathrm{p}<0.01,{ }^{* * *} \mathrm{p}<0.001$ compared to control (Nacl) (ANOVA test followed by Dunnett test)

\section{Discussion}

The present investigation was aimed to study an anti-inflammatory activity of aqueous and hydroethanolic extracts of Crinum scillifolium in animal model. In order to evaluate this activity, the carrageenan paw model has been employed. This method has been widely employed as an animal model for screening anti-inflammatory drugs and most studies have used edema as the dependent measure $[17, \mathbf{1 8}]$. Two doses 100 and $200 \mathrm{mg} / \mathrm{kg}$ body weight for each extract, were tested. The results obtained were compared with those of the standard drug (Diclofenac at 25 $\mathrm{mg} / \mathrm{kg}$ body weight) and those of the control (normal saline). It is well known that Carrageenan injection induces local inflammation caused by tissue injury, which results from the action of several chemical mediators, like prostaglandins, histamine, bradykinins, leukotriene and serotonin [19]. Indeed, the inflammatory response is a triphasic event. The initial phase $(1-2 \mathrm{~h})$ is attributed to the release of chemical mediators such as histamine and serotonin, which promotes vasodilation and plasma transudation. A second phase $(2-3 \mathrm{~h})$ involves kinins, principally bradykinin, as a mediator increasing vascular permeability and edema formation. The last phase (3-6 h) is due to the release of prostaglandins, arachidonate metabolites, neutrophil migration and release of oxygen free radicals $[\mathbf{2 0}, \mathbf{2 1}, \mathbf{2 2}]$. The results showed that Crinum scillifolium extracts inhibited significant the formation of the rat paw edema in the early and late phases (Hydroethanolic extract) and late phases (aqueous extract) and the standard anti-inflammatory drug Diclofenac significantly reduced the rat paw edema compared to the control group. The Diclofenac, used as a reference drug, is a nonsteroidal antiinflammatory drug (NSAID), which exert anti-inflammatory activity by the inhibition of cyclooxygenase (COX1 and COX2) and suppress production of chemical substances (prostaglandin, histamine and serotonin) which are involved to increase vasodilatation and vascular permeability [23, 24]. The decrease of the paw edema by the oral administration of Crinum scillifolium could be explained by the substances with antagonistic action to the histamine, the serotonin, the bradykinin and to the biosynthesis of prostaglandins. Anti-inflammatory activity of Crinum scillifolium extracts was evaluated too by estimation of levels CRP at 5 th hour during carrageenan induced paw edema in rats. Inflammatory reactions, infections, or tissue injury trigger acute phase proteins synthesis, such as CRP. It is synthesized mainly in the liver, but it may also be synthesized by local inflammatory cells in the area of tissue damage $[\mathbf{2 5}, \mathbf{2 6}]$. The results found that its levels increased at $5 \mathrm{~h}$ for group $1(\mathrm{Nacl}+$ carrageenan) and the extracts of Crinum scillifolium and diclofenac allowed to have a level of CRP getting closer to normal despite the injection of carrageenan. This indicates that Crinum scillifolium and diclofenac have potential inhibitory effects 
on acute phase protein of inflammation. The genus Crinum have also been documented to present huge number alkaloids $[\mathbf{2 7}, \mathbf{2 8}]$. While alkaloids are well known for their ability to inhibit the perception of pain and to be an anti-inflammatory [29]. The presence of these chemical compounds in the extract could be responsible for anti-inflammatory activity. Many studies have indicates that Crinum genus have been employed as anti-inflammatory agent. Pharmacological investigation of the effects of total extracts obtained from different parts of Crinum using many inflammatory models showed their potential for treatment of various inflammatory processes [30].

\section{Conclusions}

The present study confirms the anti-inflammatory effect of Crinum scillifolium and provides new evidences that a local carrageenan injection induces a systemic response, characterized by increased levels of acute phase proteins, such as CRP.

\section{Ethical Approval}

The experimental procedures and protocols used in this study were approved by the Ethical Committee of Health Sciences, University Félix Houphouet-Boigny. These guidelines were in accordance with the European Council Legislation 87/607/EEC for the protection of experimental animals. All efforts were made to minimize animal suffering and reduce the number of animals used.

\section{REFERENCES}

[1] Ashley, N. T., Weil, Z. M., \& Nelson, R. J. Inflammation: mechanisms, costs, and natural variation. Annual Review of Ecology, Evolution, and Systematics, 43, 385-406. 2012.

[2] Zhou Y, Hong Y, Huang H. Triptolide Attenuates Inflammatory Response in Membranous GlomeruloNephritis Rat via Downregulation of NF-kB Signaling Pathway. Kidney and Blood Pressure Res; 41:901-910. 2016

[3] Rana, A., \& Musto, A. E. The role of inflammation in the development of epilepsy. Journal of neuroinflammation, 15(1), 144. 2018

[4] Tatiya, A. U., Saluja, A. K., Kalaskar, M. G., Surana, S. J., \& Patil, P. H. Evaluation of analgesic and anti-inflammatory activity of Bridelia retusa (Spreng) bark. Journal of traditional and complementary medicine, 7(4), 441-451. 2017

[5] Calixto, J. B., Cabrini, D. A., Ferreira, J., \& Campos, M. M. Kinins in pain and inflammation. Pain, 87(1), 1-5. 2000
[6] Beckstrom-Sternberg SM, Duke JA and Wain KK: The ethnobotany database. Genome Informatics Group. National Agricultural Library. U.S. Department of Agriculture, Beltsville, MD, 1994.

[7] Tram, N. T. N., Titorenkova, T. V., Bankova, V. S., Handjieva, N. V., \& Popov, S. S. Crinum L.(Amaryllidaceae). Fitoterapia, 73(3), 183-208. 2002

[8] AhmadM: Cytotoxic activity of the leaf extract of Crinum asiaticum Linn. Australian Journal of Medical Herbalism; 8(1):3-6. 1996

[9] Jayaweera DM: Medicinal plants used in Ceylon. The National Science Council of Sri Lanka, Colombo, 1981.

[10] Etkin N: Plants in Indigenous Medicine and Diet: Biobehavioural Approaches. Redgrave, Bedford Hills, New York, 1986.

[11] Kapu SD, Ngwai YB, Kayode O, Akah PA, Wambebe C, and Gamaniel K: Anti-inflammatory, analgesic and anti-lymphocytic activities of the aqueous extract of Crinum giganteum. Journal of Ethnopharmacology; 78(1):7-13. 2001

[12] F. G. Guédé, Extraction of mansonin from Mansonia altissima as cardiovascular agent (patent application). Ministère de la Recherche Scientifique, Côte d'Ivoire. 35 p. 1990.

[13] OCDE. Repeated Dose Oral Toxicity Test Method. OCDE Guidelines for testing of chemicals. Organization for Economic Cooperation and Development, Paris, 327,

[14] Ratheesh M, Helem A. Anti-inflammatory activity of Ruta graveolens Linn on carrageenan induced paw edema in wistar male rats. AJB. 5 (10):1209-12111. 2007

[15] Oladosu I, Ogundajo A, Alyalaagbe O, Emenyonu N. Phytochemical and antituberculosis activity of Coffea brivipes, hiern exracts. Res J Phytochem.;5: 130e135. 2011

[16] Wick M., Pingger W. \& Lehmann L. Iron Metabolism: Diagnosis and Therapy of Anemias, 4th ed. Springer-Verlag, Vienna/New York, USA, 127p. (1996).

[17] Fehrenbacher JC, Vasko MR, Duarte DB. Models of inflammation: carrageenan- or complete Freund's adjuvant (CFA)-induced edema and hypersensitivity in the rat. Curr Protoc Pharmacol. doi:10.1002/0471141755.ph0504s56. 2012

[18] Chavan HV, Adsul LK, Kotmale AS, Dhakane VD, Thakare VN, Bandgar BP. Design, synthesis, characterization and in vitro and in vivo anti-inflammatory evaluation of novel pyrazolone-based chalcones. J Enzyme I

[19] Suba Y., Murugesan T., Kumaravelrajan R., Mandal S. C., Saha B. P. Antiinflammatory, analgesic and antiperoxidative efficacy of Barleria lupulina Lindl. extract. Phytotherapy Research;19(8):695-699. 2005

[20] Sanogo, R., Maiga, A., Diallo, D.. Activités analgesique et anti-inflammatoire des extraits de Maytenus senegalensis, Stereospermum kuntrianum et Tricrilia emetica utilisées dans le traitement traditionnel des dysmenorrhees au Mali. Pharmaceutical Medicinal Traditional African Journal 14, 123-136. 2006 
[21] Ouédraogo, N., Lompo, M., Sawadogo, R.W., Tibiri, A., Hay, A.E., Koudou, J., Dijoux, M.G., Guissou, I.P.. Etude des activités anti-inflammatoire, analgésique et antipyrétique des décoctés aqueux des feuilles et des racines de Pterocarpus erinaceus Poir. (Fabaceae). Phytothérapie 10, 286-292. 2012

[22] Kumar, T., Jain, V. Antinociceptive and anti-inflammatory activities of Bridelia retusa methanolic fruit extract in experimental animals. Scientific World Journal 2014, 1-12. 2014

[23] Chiolero, A., Würzner, G., Burnier, M., Les inhibiteurs sélectifs de la cyclooxygénase de type 2: moins d'effets rénaux que les anti-inflammatoires non stéroïdiens classiques? Néphrologie 21, 425-430. 2000

[24] Tsunumi, K., Kyuki Niwa, M., Mibu, H., Fujimura, H., Pharmacological investigation of new anti-inflammaory agent 2-(10,11-dihydro-10-oxodibenzo (b,f) thiepen-2-yl) propionic acid inhibitory effects on acute inflammation and prostaglandin related reaction. Arzneimitelforschung 36, 1801-1805. 1986

[25] Kushner I. Regulation of the acute phase response by cytokines. Perspect Biol Med; 36:611-22. 17. 1993

[26] Murata H, Shimada N, Yoshioka M. Current research on acute phase proteins in veterinary diagnosis: an overview. Vet J; 168:28-40. 2004

[27] Sun Q, Shen YH, Tian JM, Tang J, Su J, Liu RH, Li HL, Xu $\mathrm{XK}$, Zhang WD. Chemical constituents of Crinum asiaticum L. var. sinicum Baker and their cytotoxic activities. Chem. Biodivers.; 6(10): 1751-1757. 2009

[28] Zhang X, Huang H, Liang X, Huang H, Dai W, Shen Y, Zhang W. Analysis of Amaryllidaceae alkaloids from Crinum by high-performance liquid chromatography coupled with electrospray ionization tandem mass spectrometry. Rapid Communications in Mass Spectrometry. 23(18):2903-2916. 2009

[29] Metrouh-Amir, H., \& Amir, N. Evaluation in vivo of anti-inflammatory and analgesic properties of Matricaria pubescens alkaloids. South African Journal of Botany, 116, 168-174. 2018

[30] Refaat, J., Kamel, M. S., Ramadan, M. A., \& Ali, A. A. Crinum; an endless source of bioactive principles: a review. part v. biological profile. International Journal of Pharmaceutical Sciences and Research, 4(4), 1239. 2013 